\title{
Az online közösségi hálózatok és a véleménynyilvánítás pozitív és negatív szabadsága
}

A modern arab világ talán legnagyobb kortárs szerzóje, a szürreális-szatirikus írásai nyomán világhírú, szíriai prózaíró Zakaria Tamer novelláinak vissza-visszatéró témája az elnyomás: az egyén elnyomása az állami és vallási intézmények által és az egyének elnyomása egymás által.

A politikai, társadalmi és vallási autoritás kérdései képezik annak a Tamer-novellának is a tematikus magját, amelyben az özvegy Bahídzsának fia születik, Bahdzsat, aki újszülöttként is felnőttként gondolkodik, viselkedik, (elmondása szerint) ír-olvas, számol és beszél. Édesanyja ezen természetesen meglepődik és rendreutasítja, hogy hagyja abba, nehogy a kórházi alkalmazottak meghallják. „Most pont úgy beszélsz, mint a vezetőink" - oktatja ki a fia. Szófogadó gyermekként mindenesetre szavát adja, hogy többé nem szól egy szót sem. Nem is szól húszéves koráig. Ekkor a néma Bahdzsat egy pénteki délutánon elmegy a mecsetbe, ahol vallásfilozófiai és erkölcsi vitába keveredik az ottani igehirdetővel, aki amellett érvel, hogy nők és férfiak utazzanak elkülönülten a tömegközlekedési eszközökön. Miközben hallgatja, Bahdzsatból kitör a nevetés, akkor jön rá, hogy tud beszélni is. Az elmérgesedő és személyeskedővé fajuló vita eredményeként a szónok hívei, követői agyonverik Bahdzsatot.

A magától értetődően fiktív, ám annál tanulságosabb történet, ha nem is fekteti le egy elméleti fejtegetés alapjait, legalább három szempontból mégis állhat egy, a véleménynyilvánítási szabadság és a közösségi média viszonyrendszerével foglalkozó tanulmány elején.

Mindenekelőtt rávilágít, hogy a véleménynyilvánítást gyakran kísérik konfliktusok, amelyek hátterében a legváltozatosabb okok húzódnak, például a normaszegéstől az emberi méltóságig a nemzetbiztonsági megfontolásokon át.

A második észrevétel merő feltételezés: a Bahdzsat halálához vezető, „offline” incidens talán elkerülhető lett volna, ha a felek a világhálón, vagyis a „kibertérben” vitáznak.

A harmadik pedig már csak távolról és áttételesen kapcsolódik a novella konkrét cselekményéhez: ha a világháló lényegéből fakadó, tér és idő korlátait is leküzdő jelleg a fenti összetüzés elkerüléséhez is vezethet, világszerte találunk példákat arra, hogy egyes véleménynyilvánításoknak „offline” igazságszolgáltatási, vagy egyéb implikációi lehetnek.

E súlypontok mentén a tanulmány felépítése is hármas tagolású.

Az első fejezet és alegységei egy filozófiatörténeti áttekintéssel - amely a híres bölcselők releváns nézeteitől jut el a nemzetközi egyezményekben foglaltak jelenéig - indítva kísérlik meg bemutatni az véleménynyilvánítás ún. pozitív és negatív szabadságának koncepcióit és tisztázni azok viszonyát a tárgyunkkal.

A második szerkezeti egység megpróbálja elhelyezni a korábban bemutatott fejlödési íven magát a világhálót is, továbbá szemügyre veszi a közösségi médiában rejlö, véleménynyilvánítási potenciált, érveket és ellenérveket sorakoztatva fel. 
A véleménynyilvánítási szabadságnak a hálózati alapú kommunikációval, egyszersmind az online közösségi hálózatokkal (a továbbiakban: $\mathrm{OKH}$ ) összefüggö, lehetséges implikációi akkor a legnyilvánvalóbbak, ha annak jogi következményei vannak. A harmadik fejezet éppen ezért bemutat egy esettanulmányt, a Smith vs. Trafford Housing Trust-ügyet Nagy-Britanniából Dominic McGoldrick (2013) nemzetközi emberi jogi professzor értékelése nyomán, amely a fenti novellához hasonlóan számos tanulsággal szolgál a kérdéskört illetően. Leginkább pedig azt jelzi, hogy e jog csorbításának ,veszélye" nemcsak az Államtól várható - amint azt a tekintélyelvủ diktatúrák, és a megfigyelést gyakorló jogállamok példái sugallják - hanem a profittermelés céljának mindent felülíró parancsa miatt a magánszektortól is, ebben az esetben pedig maga a jogállam veheti kezébe az igazság(szolgáltatás) pallosát.

\section{A véleménynyilvánítás és annak szabadsága}

A Kommunikációtudományi Nyitott Enciklopédia definíciója szerint a szó legtágabb értelmében a véleménynyilvánítás bizonyos belső mentális állapotok, propozicionális attitüdök kommunikálását jelenti. Ebben az értelemben véleménynyilvánításnak tekinthetö egy tényítélet megfogalmazása éppúgy, mint egy pusztán szubjektív vélemény megfogalmazása. ${ }^{1}$

A véleménynyilvánítás fogalmának tartalmát az is befolyásolhatja, hogy milyen igazolást választunk a véleményszabadság számára.

A véleménynyilvánítás értelmezhető önkifejezésként:

„A véleménynyilvánítás részben tehát a beszélő önkifejezésének, személyisége szabad kibontakozásának lehetősége. A véleményszabadság individuális igazolása alapján a kommunikációhoz való jogot nemcsak következményei támasztják alá, hanem az a mindenkit megillető morális jog, hogy azt mondjon, amit akar.' (Gálik-Polyák, 2005, 58. o.)

Ebben az értelemben tehát a véleménynyilvánítás önkifejezés, a véleményszabadság pedig a kifejezés szabadsága.

Ami pedig a véleménynyilvánítást mint a társadalmi nyilvánosság eszközét illeti, a 30/1992. (V. 26.) alkotmánybírósági határozat fekteti le azokat az elvi alapvetéseket, amelyek értelmében „a szabad véleménynyilvánításhoz való jog a fentiek szerint nem csupán alapvető alanyi jog, hanem e jog objektív, intézményes oldalának elismerése egyben a közvélemény, mint alapvető politikai intézmény garantálását is jelenti”. E döntés - noha azt mindenekelött a gyülöletbeszéd szabályait vizsgálva idézi a magyar jogtudomány - valóban jóval többről, a demokratikus nyilvánosság kívánatos képéről, feltételeiről, elemeiről, terheiről is szól (Székely, 2013, 11. o.), így témánk nem jogspecifikus aspektusaihoz is kapcsolódó pontokat kínál:

„A véleménynyilvánítás e megközelítésben tehát az az eszköz, amely müködteti a társadalmi nyilvánosságot, és a vélemények nyilvános ütköztetésével biztosítja az egyén megalapozott véleményalkotásának és demokratikus részvételének feltételeit (instrumentális igazolás)" (Gálik-Polyák, 2005, 58. o.).

Muḥsin aš-Šayh Āl Ḥassān (2013) szaúd-arábiai író és médiakutató értelmezése rámutat, hogy a véleménynyilvánítás, mint önkifejezés szabadsága nem abszolút és - a fentebb felmerülő jogi szövegkörnyezet által sugalltakhoz hasonlóan - a gyakorlatban a mindenkori jogi keretekhez illeszkedik: 
„a vélemény és a kifejezés szabadsága úgy határozható meg, mint a vélemények és gondolatok kifejezésének szabadsága szóban, írásban vagy müvészeti alkotás formájában, cenzúra, vagy hatalmi korlátozások nélkül, feltéve, hogy e nézetek és elképzelések formája és tartalma nem minősül a véleménynyilvánítási szabadságot lehetővé tevő állam törvényeinek és szabályainak a megsértésének. A véleménynyilvánítási szabadságot gyakran kísérik jogok, kötelességek és korlátozások. Ami a véleménynyilvánítási szabadságot illeti, ez az egyik legkényesebb és legérzékenyebb kérdés, hiszen a hatalom (a kormányzat, vagy más érdekeltek) által meghúzott határok képlékenyek, a társadalompolitikai körülményrendszernek megfelelően változnak, politikai és állambiztonsági keretektől, vagy a különböző államalkotó, társadalmat felépítő nemzetiségi, felekezeti, vallási stb. arányoktól, esetleg egyéb, külső tényezőktől függenek."

\section{Filozófiatörténeti áttekintés}

A véleménynyilvánítás szabadságához kapcsolódó kérdések hosszú történelemre tekintenek vissza, amely megelőzi a modern, nemzetközi emberi jogi megállapodásokat - amelyekről még szót ejtünk a későbbiekben -, ad absurdum az online közösségi hálózatok megjelenését.

Egyes feltételezések szerint a szólás szabadságának demokratikus eszmerendszere az ókori Athénben az időszámításunk előtti 5-6. században jelenhetett meg (Raaflaub, Ober és Wallace, 2007, 65. o.). A Római Köztársaságban pedig a legbecsesebb értékek közé tartozott a vallásszabadság mellett a szólás szabadsága is (Charlesworthe, 1943, 49. o.).

Ezen értékek intézményesüléséröl hosszú évszázadokon keresztül nem állnak rendelkezésre ismeretek. A későbbiekben a véleménynyilvánítás szabadságának kérdése az egyházi tanok és ellenhatásaik, illetve az utóbbiakkal szembeni fellépések, vagyis a cenzúra ${ }^{2}$ köré fonódik.

Mielőtt megjelent a nyomtatás, egy iratot csakis fáradságos és hibára hajlamosító másolómunka árán lehetett sokszorosítani. A cenzúrának és ellenőrzésnek nem volt kidolgozott rendszere, az a 14. századig a vallási intézményekre korlátozódott, amelyek iratait ritkán övezte szélesebb körü vita. Válaszul a nyomtatás kihívásaira és az eretnek tanok ezt kísérő terjedésére, a római katolikus egyház a tartalomellenőrzés felé mozdult el (de Sola Pool, 1983, 14. o.). A nyomtatás lehetővé tette egy munka sokszorosítását (a nagyobb ,példányszámot”), ami a nézetek és információk gyorsabb ütemü és szélesebb körü keringését eredményezte. A szerzői jog eredete az európai országokban a római katolikus egyháznak a nyomtatás hatáskörének szabályozását célzó erőfeszítéseiben gyökerezik (MacQueen, 2007, 34. o.).

1501-ben VI. Sándor pápa egy — később az egyházra nézve — egyetemes érvényű — cenzúra-szabályzatot dolgozott ki a nem engedélyezett könyvek nyomtatásával szemben, és a történelem folyamán talán először, 1559-re összeállt az Index Expurgatorius (vagy Index Librorum Prohibitorum), vagyis a tiltott könyvek jegyzéke (de Sola Pool, 1983, 14. o.). A „rossz könyvek” katalógusa, amely háromszáz kiadást ért meg, egyben feltehetőleg a leghírhedtebb és leginkább időtálló példa a doktrínákkal szembekerülő gondolatok és vélemények ellenőrzésére, elfojtására. Tartószerkezete és működtető intézménye a Szent Inkvizíció volt, ám érvényre juttatásában helyi hatóságok is közremüködtek. Ennek megfelelően kerültek „,feketelistára” René Descartes, Giordano Bruno, Galileo Galilei, David Hume, John Locke, Daniel Defoe, Jean-Jacques Rousseau és Voltaire müvei is (Castillo, 2010, 14. o.). Amíg az udvarok, kormányzatok és az egyház ösztönözték a szentiratok, felhívások stb. nyomtatását, az eltérő vélemények és bírálatok szintén gyorsan terjedhettek. Következőleg az udvarok, kormányzatok kialakították a nyomtatás 
ellenőrzését Európa-szerte, a könyvek forgalmazását és a velük való kereskedést hivatalos engedélyhez kötve (MacQueen, 2007, 34. o.).

Az az elképzelés, hogy az eltérő, adott esetben „felforgató” véleményt el kell türni, nem pedig cenzúrának kitenni vagy törvény által büntetni, a nyomtatás és a sajtó felemelkedésével karöltve járt. Az 1644-ben kiadott Areopagitica John Milton (1608-1674) válasza volt a nyomtatók és kiadók kormányzati engedélyhez való kötöttségének angol törvényhozás általi, újbóli bevezetésére (Sanders, 2003, 66. o.). Előzőleg az egyházi hatóságok gondoskodtak arról, hogy az angol irodalmár esszéje ne kaphasson kiadási engedélyt.

Az engedély nélkül kiadott Areopagitica Milton szenvedélyes védőbeszéde a véleménynyilvánítási szabadság mellett: ,adjátok nekem meg annak jogát, hogy lelkiismeretem szerint tudhassak, jelenthessek ki és érvelhessek, minden más szabadságot megelözően" (Sanders, 2003, 66. o.).

Miltonhoz hasonlóan John Locke (1632-1704) is azon angol gondolkodók egyike, akik a véleménynyilvánítás szabadságáról szóló korai vita élvonalához tartoztak. Locke az egyént állította mértékegységül és megtette az élethez, a szabadsághoz, a tulajdonhoz és a boldogság kereséséhez való jog hordozójának. Azonban Locke nézetei elsődlegesen a lelki üdvözülés kereséséhez való jog köré fonódtak, imigyen ő föként teológiai kérdésekkel foglalkozott. Locke nem támogatta a szólásszabadság tolerálásának egyetemességét, így egyes csoportok, például az ateisták szerinte nem részesülhetnek annak védelmében (Israel, 2002, 265-267. o.).

Locke-nál is szerepel a társadalmi szerződés gondolata. Nála azonban a feltételezett ösi természeti állapotot nem a Hobbes-i „mindenki harca mindenki ellen” sajátosság, hanem a szabadság, a béke és a magántulajdon egyenlősége jellemzi. Ám ezt az eredeti helyzetet megfelelő béklyózó erők hiányában egyesek megzavarhatják (pl. lopás és gyilkosság révén több vagyonra igyekeznek szert tenni, mint amennyi megilleti öket), s ennek következtében megrendülne az ösi állapot. Annak érdekében aztán, hogy ez ne következhessék be, kell, hogy az állam létrejöjjön, törvényeket hozzon, s az utóbbiak áthágóit a szabadság és a magántulajdon megőrzése céljából büntetéssel sújtsa (Pais, 2005, 515. o.). Mindez már felveti az egyik oldalon a (közérdek megvalósulását célzó) egyéni felelösség, a másik oldalon pedig az elidegeníthetetlen jogok állam általi garanciájának kérdéseit.

A 17. század második felére olyan bölcselők, mint Baruch Spinoza és Pierre Bayle, kidolgozták a véleménynyilvánítás szabadságának és a toleranciának a korábbiaktól egyetemesebb aspektusait felölelö elképzeléseiket (Israel, 2002, 265-267. o.). A 18. századra az ideát olyan gondolkodók karolták fel, mint Diderot, d'Holbach báró, és Helvétius (Israel, 2006, 155. o.). A fogalom elkezdett gyökeret ereszteni a politikaelméletbe, mind elméletben, mind gyakorlatban.

A történelem első államrendelete, amely kimondja a szólás teljes szabadságát, a dán-norvég unióban került kihirdetésre 1770. december 4-én Johann Friedrich Struensee kormányzósága alatt (Israel, 2010, 76. o.). Mindazonáltal maga Struensee volt az, aki kisebb korlátozásokat léptetett életbe a rendelet alkalmazását illetően alig egy szük évvel később, majd a kormányzó bukását követően 1773-ban e jogot tovább korlátozták, igaz, a cenzúrát már nem vezették újra be (Barton, 1986, 90-91. o.).

A véleménynyilvánítási szabadság első harcosai - a szabadság igényének megfogalmazódása idején fennálló társadalmi rend jellegéből természetszerüleg adódóan - elsődlegesen az Államtól való függetlenség szükségességét hirdették. A szabad szólás és sajtó igénye azonban soha nem öncélként tételezödött, hanem a társadalom átformálásához, az igazságosabb politikai berendezkedés megvalósításához, később már a szélesebb néprétegek demokratikus döntéshozatalba való bevonásához szükséges eszköz volt (Koltay, 2012) - amint ezt jelen történelmi áttekintés is világossá teszi. 
John Stuart Mill (1806-1873) nézete szerint az emberi szabadság nélkül nem fejlődhet a tudomány, a jog és a politika, amelyek mind igénylik a nézetek szabad kifejtését, megvitatását. Mill 1859-ben kiadott müve, az On Liberty, a véleménynyilvánítási szabadság egyik kiemelkedő, klasszikus védőbeszéde (Sanders, 2003, 66. o.). Mill azzal érvelt, hogy az igazság kiüzi a hamisságot, ennélfogva pedig nem kell tartani a gondolatok szabad megvitatásától, akár igazak azok, akár hamisak. Az igazság nem stabil vagy rögzített, hanem az idő múlásával alakul. Szerinte sok minden, amit valaha igaznak fogadtunk el, azóta már hamissá lett - a történelem bőven szolgáltatott példát arra, hogy öröknek hitt dogmák elveszítsék megkérdőjelezhetetlenségüket, majd megdőljenek. Éppen ezért a nézeteket látszólagos hamisságuk miatt nem szabad betiltani, hiszen soha nem tudhatjuk, hogy nem éppen az igaz álláspontot nyomjuk-e el a szabadság korlátozásával. A szabad véleménycserére szükség van annak érdekében, hogy ne sodródjunk a megszilárdult vélemény „mély álmába". A diszkusszió elősegíti az igazság diadalmenetét és a hamis nézetek mérlegelésével az igaz nézetek újbóli megerösítést nyernek (Sanders, 2003, 67. o.). Ezen kívül Mill szerint a vélemény csak a tulajdonosa számára bír belső értékkel, következőleg ennek a véleménynek az elhallgattatása alapvető emberi jogot sért. Mill számára az egyetlen eset, amikor jogszerúen korlátozni lehet a szólást, akkor áll fenn, ha meg kell akadályozni egy nyílt és közvetlen fenyegetést. Sem társadalmi, sem erkölcsi következmények, sem a beszélő saját jóléte nem igazolja a beszéd elnyomását (Warburton, 2009, 24-29. o.).

Voltaire nevéhez füződik az a mások (Boller és mtsai, 1989, 124-126. o.) szerint „,apokrif” idézet, amelyet gyakran a szólásszabadság (egyik) alapelvének körülírására használnak, és amely úgy szól, hogy „nem értek egyet azzal, amit Ön mond, de életem végéig harcolni fogok azért, hogy azt elmondhassa".

A múlt században Noam Chomsky megállapította, hogy „ha az ember hisz a szólás szabadságában, akkor az ember által nem kedvelt nézetek kinyilvánításának szabadságában is hisz. Sztálin és Hitler például csakis az általuk kedvelt nézetek szabadságát előnyben részesítő diktátorok voltak. A szólásszabadságban hinni annyit tesz, mint éppen azokat a nézeteket tolerálni, amelyeket az ember megvet" (Achbar és Wintonick, 1992).

Az idők folyamán változó, releváns elképzelések a nemzetközi egyezmények tartalmaiban csúcsosodtak ki, amelyek kodifikációs előzményei már a francia Emberi és polgári jogok nyilatkozatának 11. cikkelyében is fellelhetők:

„A gondolatok és vélemények szabad közlése az embernek egyik legértékesebb joga; ennélfogva minden polgár szabadon szólhat, írhat s nyomtathat ki bármit, felelösséggel tartozván viszont e szabadsággal való visszaélésért a törvény által meghatározott esetekben."

A Polgári és Politikai Jogok Nemzetközi Egyezségokmányának - amelynek Magyarország is szerződő fele - 19. cikkelye a következőképpen fogalmaz a véleményszabadsággal kapcsolatban:

1. Nézetei miatt senki sem zaklatható.

2. Mindenkinek joga van a szabad véleménynyilvánításra; ez a jog magában foglalja mindenfajta adat és gondolat határokra való tekintet nélküli - szóban, írásban, nyomtatásban, művészi formában vagy bármilyen más tetszése szerinti módon történő keresésének, megismerésének és terjesztésének a szabadságát is.

3. Az e cikk 2. bekezdésében meghatározott jogok gyakorlása különleges kötelezettségekkel és felelősséggel jár. Ennél fogva az bizonyos korlátozásoknak vethető alá, ezek azonban csak olyanok lehetnek, amelyeket a törvény kifejezetten megállapít, és amelyek a) mások jogainak vagy jó hírnevének tiszteletben tartása, illetőleg

b) az állambiztonság vagy a közrend, a közegészség vagy a közerkölcs védelme érdekében szükségesek. 
Jürgen Habermas (2006, 119-120. o.) írja A posztnemzeti állapotról szóló esszéjében, hogy bizonyos értelmezések szerint az emberi jogi diskurzus (amelynek magától értetődően szerves része a véleménynyilvánítás szabadságának kérdésköre is) és a nemzetközi egyezményekben kodifikált tartalmak egyetemes érvényességének, egalitarianizmusának normatív feltételrendszere mögött a Nyugat álnok hatalmi törekvései állnak. Ami jelzi egyfelől az emberi jogi diskurzus legitimációs és más elvi vitákkal átszőtt jellegét, másfelől pedig azt sugallja, hogy a mögöttes tartalom kapcsán adott esetben partikuláris kódrendszerekről van szó, amelyek kultúránként változó érvénnyel bírnak.

Ahogy tágabb értelemben az emberi jogokkal, úgy a szólásszabadsággal kapcsolatban is felmerül az ideológiai töltés kérdése: következzék Hashmat Moslih (2014) afgán politológus okfejtése az emberi jogok problematikájáról egy kulturálisan sokszínü globális környezetben. Bár versengő ideológiai szempontok alkalmazzák az emberi jogok kifejezést a mindennapi politikai diskurzusban, nem világos, hogy a 'jogok' mire utal, azt hogyan értelmezzük. Ha a jogok alatt jogosultságot értünk valamire, netán azt egyenesen egy bizonyos módon való bánásmódra való jogosultságként fogjuk fel, számos kérdés merül fel.

Honnan származik ez a jogosultság és ki határozza meg ennek a jogosultságnak a korlátait? Az „egyetemes emberi jogok” fogalom középpontjában az a feltevés áll, hogy minden ember egyenlő. Ez az egyenlőség egyenlö jogokként, vagy egyenlő jogosultságként értendö-e a valóságban, az egyenlőtlenségek világában? Hogy határozzuk meg az egyenlőséget, vagy igazságot, hogy definiáljuk magát az embert?

Lehetetlen az emberi jogok önmagába vissza nem térő, nem körkörös jellegü, összehangolt filozófiáját megalkotni - írja Moslih. Az emberi jogok kérdése ugyanis összefonódik az igazság kérdésével, az igazság kérdésének lényegi eleme a boldogság kérdése, ami pedig a jólét kérdésével kapcsolódik össze. De vajon hogy határozzuk meg ezeket a fogalmakat? Lehetséges-e mindez ideológia nélkül? Vajon ezek értéksemlegesek-e?

Jelen tanulmány tudatosan törekszik arra, hogy az európai fejlödéstörténet mellett más kulturális mintákat és hagyományokat is érintsen, így egy muszlim perspektívát is. ${ }^{3}$

Muḥsin aš-Šayh Āl Ḥassān (2013) szerint a véleménynyilvánítás az iszlám szempontjából ,a hatalmon lévő és az alattvaló kötelessége egyaránt”, amelyet a hatalmon lévő a konzultáción (arabul: šūrā) keresztül köteles gyakorolni, igazságosan és az igazságszolgáltatási rendszer függetlensége, a közmüvelődés és a gazdasági jólét által, és minden más eszközzel, amivel csak lehetséges, annak érdekében, hogy az állampolgárnak ne kelljen félnie az elnyomástól, sem a szegénységtől, sem a marginalizálódástól. Az állampolgárok pedig mind egyénileg, mind csoportosan kötelesek a hatalmon lévők és a többiek tekintetében a véleménynyilvánítást gyakorolni, hiszen e nélkül „,romlás érné a muszlim társadalmat", az igazhívő következőleg köteles felszínre hozni politikai, társadalmi és jogi hitvallását. Ez nem azt jelenti, hogy másokat sértegetünk, megvádolunk, felfedünk vagy meghazudtolunk a véleménynyilvánítási szabadság nevében.

A Korán-exegézis a következő ájákban véli felfedezni a véleménynyilvánítási szabadság hermeneutikus alapjait, amelyek az annak gyakorlását legalább is implicit előkészítő iszlám vallási elöírásokként is felfoghatók:

„Ne titkoljátok el a tanúságtételt! Aki eltitkolja azt, annak bünös a szíve, Allah tudja azt, amit cselekszetek" (Korán, 2: 283).

A véleménynyilvánítás szabadsága a nézeteltérések, a konfliktusok realitásával kapcsolódik össze, amint ezt az alábbi három ája is alátámasztja: 
„Ha a te Urad úgy akarta volna, akkor egyetlen népet rendelt volna el. Ám ők még mindig egyenetlenkednek" (Korán, 11: 118)

„...ha valamiben összekülönböztök, vigyétek azt Allah és a küldött elé, ha hisztek Allahban és a Végső Napban” (Korán, 4: 59).

„A hívő férfiak és a hívő nők egymás gyámolítói. Azt parancsolják meg, ami helyénvaló, és azt tiltják meg, ami elvetendő" (Korán, 9: 71).

A muszlim perspektíva - még akkor is, ha történetesen egy eurocentrikus nézőpont gyakran az iszlám, vagy más gondolatrendszerek kulturális dominanciája alá került területeken meg is kérdőjelezi a véleménynyilvánítás szabadságának létét és gyakorlati megvalósíthatóságát - is sejteti az emberi méltóság és véleménynyilvánítási szabadság (szabadság és egyenlőség?) már-már kibékíthetetlen, kultúrákon átívelő ellentétét.

Ha elfogadjuk premisszaként, hogy itt egy ellentmondásról van szó, akkor ahhoz az elvi vitához jutunk, amelyet a valamire, illetve a valamitől való szabadság ellentétpárja határoz meg.

A ,pozitív” és a „negatív” szabadságfogalmak Isaiah Berlin (1990, 334-443. o.) filozófus klasszikussá vált esszéjében jelennek meg először. Berlin az egyén számára biztosított, külső közbelépés nélküli mozgásteret „negatív” (valamitől, valakitől való) szabadságként értelmezi, míg a döntési szabadságot, tehát azt, hogy az egyén saját maga ura legyen, ,pozitív” (valamire való) szabadságként. Vagyis amíg a negatív szabadság tulajdonképpen formális, jogi értelemben vett egyenlőséget nyújt, addig a pozitív a valós cselekvési potenciált, tehát a formális egyenlőség hatékony alkalmazását határozza meg.

Ha nem is kifejezetten Berlin megfogalmazásában, ám e két eltérő szabadság közötti egyensúly problematikája feltehetőleg egyidős magával az emberiséggel és elvi, filozófiai viták tárgya volt és talán lesz mindig is, és magától értetődően magára a véleménynyilvánítási szabadságra is átgyürüzött. Különösen pedig a szabályozásról szóló diskurzusban köszön(t) vissza.

A történelmi fejlődés során természetszerűleg világszerte a véleménynyilvánítási szabadság negatív jellege került elsőként hangsúlyozásra, amely jogot akkor a cenzúra tilalmával (amely, mint tudjuk, az 1848-49-es forradalom és szabadságharc követeléseit csokorba foglaló 12 pont előkelő első helyére is került) azonosítottak, melynek megfelelő a vélekedés, hogy az „előzetes vizsgálat” eltörlése magával hozná a sajtó, tehát a nagyobb közösség előtt történő véleménynyilvánítás teljes szabadságát. Ez a felfogás kevéssel a cenzúrát megszüntető törvények elfogadása után átértékelésre szorult. A sajtó szabadságába történő külső beavatkozás a „hagyományos” médiumok kontextusában jóval szélesebb körben lehetséges (Koltay, 2012).

A szólásszabadság egyik, az egyéni szabadság fontosságára erőteljes hangsúlyt helyező olvasata szerint az egyéniség kiteljesítéséhez való jog nemcsak az Állammal, hanem a többséggel, a közösséggel szemben is megilleti az egyes embert. A szabadság individualista és közösségelvű felfo- gása olykor feszültségbe kerülhet egymással, a gyakorlatban pedig nem ritkán mérlegelésre van szükség az egyéni, individualista jog és a közösség érdeke között (Koltay, 2012).

Ronald Dworkin (1996, 195-213. o.) amerikai jogfilozófus felfogásában a szabadság korlátozása - akár akaratlanul is - éppen ezt az alapvető demokratikus értéket, tehát az egyén morális, felelős lényként való elismerését ingatná meg, ez pedig a vélemény közlőjén túl a közösség számára is káros és egyenlőtlenséget eredményez.

Ugyanakkor érdemes felidéznünk a szintén amerikai jogászprofesszor Steven Heymannek (2008, 174-179. o.) azt az érvét, amely párbajra hívja e megközelítést. Ez alapján az emberi méltóságot sértő vélemények éppen ezt a minden embert megillető 
egyenlőséget támadják, vagyis ellentétesek a felállított demokratikus játékszabályokkal, ezért a nézetpiacról kizárhatók.

E vita ellentmondó érvkészletei is előrevetik azt a ténymegállapítást, hogy a véleménynyilvánítás szabadsága sehol, egy országban sem abszolút és gyakran övezik korlátozások, amelyek motívumai között szerepel a becsületsértés, a rágalom, a trágár nyelvezet, a szemérmetlenség és a pornográfia, a blaszfémia, a gyülöletbeszéd, a büncselekményekre való felbujtás, a minősített információ, szerzői jogok megszegése, üzleti titkok, titoktartási megállapodások és egyebek.

A véleménynyilvánítás jogának intézményesülésével és gyakorlati megvalósulásával kapcsolatban gyakran kerül szóba az Egyesült Államok, ahol az alkotmány első kiegészítése megtiltja a Kongresszus számára azt, hogy a szólás szabadságát korlátozó jogszabályt fogadjon el.

Mindez bizonyos értelmezések szerint a szabadpiaci gazdaság ideáljára (és annak a távközlési, a média- és az információtechnológiai ágazatokra átvitt félreértelmezésére) vezethető vissza, amennyiben széles körű az a feltételezés, hogy a kormányzat, ha szabályozná a kommunikációs ,piacot,” vagyis beavatkozna az „árucikként” felfogott beszéd „forgalmába”, megsértené az eszményi, szabadversenyes kapitalizmus eszméjét. Ennél fogva a véleménynyilvánítás szabadságának megvalósulása valójában a fogyasztói szuverenitás megtestesülése, és közvetve gazdasági érdekekkel fonódik össze. Lényegében pedig nagyobb retorikai hatalmat biztosít nemcsak a jogtalan kormányzati cenzúra bírálatának, hanem a véleménynyilvánítás ún. negatív szabadságának a koncepciójára is hangsúlyt helyez (Sunstein, 2009, 168-175. o.).

A véleménynyilvánítás szabadságának alapelve Sunstein szerint kettős életet él: az egyik az igazságszolgáltatás, tehát a tárgyalótermek, a másik pedig a közélet, tehát a nyilvános vita szférája. Az előbbi magasztos, demokratikus célok ${ }^{4}$ érdekében, bizonyos esetekben zöld lámpát adna a véleménynyilvánítás korlátozásának (amint arra az európai földrészen számos példát találni, pl. Németország és Olaszország), ám az utóbbi, vagyis a „lobbisták, szerkesztőségek, rádiós és televíziós stúdiók, egyszerü háztartások” világának kulturális nyomása miatt egyelőre vonakodik átfogó rendezőelvek lefektetésére.

A fogyasztói szuverenitás védelme mint szempont és a demokratikus célok szolgálatában történő értelmezés közötti konfliktus - amelyet a fenti logika gerjeszt - feloldása egyelöre még várat magára.

Az, hogy a szólásszabadság abszolút, Sunstein (2009, 175-176. o.) szerint egy „társadalmilag üdvös mítosz", ugyanis még az Egyesült Államokban is tiltás övezi egyebek mellett: a számítógépes vírusokat, az engedély nélküli orvosi tanácsadást, a megvesztegetést, az elnökkel szembeni merénylettel való fenyegetőzést, a zsarolást, a büncselekmény elkövetésére való felbujtást, a gyermekpornográfiát, a szerzői jogok megsértését, a hamis hirdetést és akár a tisztán szóban történő csalást.

A társadalmi rendet megzavaró kifejezések korlátozhatósága tekintetében az Egyesült Államok jogrendszere sajátságos megoldást alakított ki. E kifejezések az USA-ban mint látjuk - példátlanul széles védelmet élveznek, ami európai szemmel idegenül hathat, ennek ellenére a választott megoldás egyes elemei fel-felbukkannak földrészünkön is: a híres-neves 'clear and present danger' (tehát „nyilvánvaló és közvetlen veszély”) elve a már a jelen tanulmányban érintett 1992-es AB-határozatban is visszaköszönt, igaz, nem elsősorban a közrend, hanem a gyülölködő kifejezések elleni védelem összefüggésében (Koltay, 2013, 138. o.).

Sunstein $(2009,177-182$. o.) okfejtése szerint a demokratikus célok szolgálatában álló strukturális szabályozás kifogásolhatatlan alkotmányjogi szempontból. Az alkotmányjogász Michel Rosenfeld (1990, 596. o.) pedig odáig megy, hogy a pozitív szólásszabadság nélkül egyenesen maga a népuralom forog veszélyben, hiszen annak híján ,a hatalom koncentrációjának és a monopolizálódás tendenciájának a támasztékáról van szó”. 


\section{A véleménynyilvánítás és a közösségi média}

\section{A közösségi média}

A közösségi média és más hálózati alapú közösségi hálózatok forradalmasították a modern kommunikációt, ami annak ellenére is tény, hogy magának a jelenségnek a tárgyszerü, letisztult megítélése még várat magára és a nyilvános részvétel és az új technológiák viszonyrendszeréröl alkotott felfogásunk meglehetősen ellentmondásos (Iványi, 2014a).

Havi rendszerességgel jóval több, mint egymilliárd személy használja aktívan a Facebookot (Kiss, 2014), beleértve szervezeteket, így a föbb emberi jogi intézményeket is. Ez a tevékenység az egész világra kiterjed, ugyanakkor aránytalanul összpontosul Európára, az amerikai kontinensre és Ausztrálázsiára (La Rue, 2011). ${ }^{5}$

Ami a 2006-ban alapított ismeretségi hálózatot és mikroblog-szolgáltatást, a Twittert illeti: az általa a száznegyven leütés terjedelmű szövegalapú üzeneteket olvasók és írók (a „tweetelők”) száma már 2012-ben meghaladta a félmilliárdot. Ök napi több mint háromszáznegyvenmillió tweetet küldenek és több mint másfél milliárd keresést folytatnak naponta (Goldrick, 2013).

Ezek a fejlemények nyilvánvalóan meghaladják a legfontosabb nemzetközi emberi jogi egyezményeket, amelyek a véleménynyilvánítás szabadságával kapcsolatos normákat tartalmazzák. Azonban ezen rendelkezések - mint látni fogjuk - gyakran tágabb értelmüek.

Az első fejezetben megállapítást nyert, hogy a véleménynyilvánítás szabadsága nem abszolút és korlátokba ütközik. A kibertérben részben hasonló kereteket találunk, ezekről majd a továbbiakban lesz szó.

\section{Az online közösségi hálózatok és a nemzetközi egyezmények}

Az Emberi Jogok Európai Egyezményének (EJEE) 10 (1). cikke kimondja, hogy „Mindenkinek joga van a véleménynyilvánítás szabadságához. Ez a jog magában foglalja a véleményalkotás szabadságát és az információk, eszmék megismerésének és közlésének szabadságát országhatárokra tekintet nélkül és anélkül, hogy ebbe hatósági szerv beavatkozhasson." Ez magában foglalja azokat a különböző, változatos alakzatokat és eszközöket, amelyekben az információ és a gondolatok megnyilvánulnak, továbbíttatnak és fogadtatnak.

Az Emberi Jogok Európai Bírósága (EJEB) foglalkozik az internetes kommunikáció néhány aspektusával (Vajic és Voyatis, 2012), ám az OKH-okra vonatkozó kérdésekkel nem. Az EJEB szerződő felei számára, még ha a testület az online közösségi hálózatok megnyilvánulásait kis értékünek tartja is, a rájuk vonatkozó szabályozásnak eleget kell tennie az EJEE 10 (2). cikkének rigorózus követelményeinek:

„E kötelezettségekkel és felelősséggel együtt járó szabadságok gyakorlása a törvényben meghatározott, olyan alakszerüségeknek, feltételeknek, korlátozásoknak vagy szankcióknak vethető alá, amelyek szükséges intézkedéseknek minősülnek egy demokratikus társadalomban a nemzetbiztonság, a területi sértetlenség, a közbiztonság, a zavargás vagy bünözés megelőzése, a közegészség vagy az erkölcsök védelme, mások jó hírneve vagy jogai védelme, a bizalmas értesülés közlésének megakadályozása, vagy a bíróságok tekintélyének és pártatlanságának fenntartása céljából." 
Az EJEB régóta fennálló ítélkezési gyakorlata az, hogy a véleménynyilvánítás joga magába foglalja olyan dolgok kimondásának jogát is, „amelyek sértik, sokkolják vagy zavarják az államot, vagy a lakosság egyéb ágazatait”. Az ENSZ különmegbízottja a szólásszabadság vonatkozásában szintén ezt a megközelítést vallja ( $L a$ Rue, 2011). Emlékeztetöül: a Polgári és Politikai Jogok Nemzetközi Egyezségokmányának 19 (2). cikkelye szerint „mindenkinek joga van a szabad véleménynyilvánításra; ez a jog magában foglalja mindenfajta adat és gondolat határokra való tekintet nélküli - szóban, írásban, nyomtatásban, müvészi formában vagy bármilyen más tetszése szerinti módon történő keresésének, megismerésének és terjesztésének a szabadságát is."

Az Emberi Jogi Bizottság (EJB) értelmezése és ítélkezési gyakorlata során nem támadt fogalmi nehézség abból, hogy az előbbi rendelkezés hatálya a világhálóra is kiterjedjen. A véleménynyilvánítás eszközeihez tartozik ,az elektronikus és hálózati alapokon történő kinyilvánítás minden formája”. Az EJT ajánlása értelmében biztosítani kell azt, hogy a tömegmédia törvényhozó és közigazgatási keretei összhangban vannak a 19. cikkely (3) bekezdésével, amely arról rendelkezik, hogy a cikkely második bekezdése által biztosított jogok gyakorlása kötelességekkel és felelősségekkel jár. Emiatt bizonyos korlátozásoknak lehet kitéve, ám csakis a törvény által meghatározott módon, ha arra szükség van. Egy: mások jogainak és hírnevének védelmében. Kettő: a nemzetbiztonság és a közrend ('ordre public'), a közegészség és a közerkölcs védelmében. A szabályozó szerveknek figyelembe kell vennie a nyomtatott és a sugárzott ágazatok, valamint a világháló között húzódó különbségeket, tekintettel ugyanakkor arra a módra is, ahogyan a különböző médiumok konvergálnak. Bármely, a weblapokat, blogokat, vagy más hálózati alapú, elektronikus vagy ilyen jellegü információterjesztő rendszert érő korlátozás, beleértve azokat a rendszereket is, amelyek az ilyen kommunikációt támogatják, mint az internetszolgáltatók vagy keresőprogramok, csak addig a mértékig engedélyezett, amíg az összhangban van a 19. cikkely (3) bekezdésével.

Az EJB tudomásul vette azt, hogy az újságírás egy olyan rendeltetés, ami szereplők széles körének sajátja, beleértve a bloggereket és másokat, akik önállóan adnak ki tartalmakat a világhálón és másutt.

\section{A közösségi média és a benne rejlö véleménynyilvánítási potenciál}

A korlátozott nyilvánossággal foglalkozó Angelusz Róbert szerint az úgynevezett látens nyilvánosság hátterében ,piramisszerü szociológiai szerkezetek körvonalazódnak, amelyekben a hatalmi központ olyan mértékben integrálta a véleménynyilvánítás és az érdekérvényesítés különböző intézményeit, hogy az az autonóm véleményformálás és véleménynyilvánítás alapjainak megroppanásához vezetett" (Angelusz, 1996, 20-21. o.).

Egy korábbi tanulmányomban elvileg nem zártam ki, hogy a közösségi média ebben a környezetben a szabad övezetek kiterjedéséhez is vezethet, a védett, állami sajtómonopólium megtörésének eszköze is lehet, ugyanis, ha hihetünk az egyiptomi blogger Váil Ghoneimnek, akkor ,a technológia elkerülhetetlenné teszi a nyilvánosságot” (Iványi, 2014a).

A közösségi médiában rejlő esetleges „egyenlösíto”” (McQuail, 2003, 127. o.) potenciálról, az információ és a befolyás monopolisztikus, állami és/vagy gazdasági forrásaitól való függetlenítő hatásairól, valamint a hiteltelenné váló tömegkommunikációs eszközöket felváltó, alternatív szerepéről többen (például: Russell W. Neuman, Stephen Coleman, Rami G. Khouri, Váil Ghoneim) írtak az elmúlt években. A tavaly nyári, brazíliai úgynevezett ecetforradalomról (Revolta do Vinagre) beszámoló média kollektíva, a Coletivo Nigèria így látja a közösségi médiát ebben az összefüggésben: 
„Azt láthatjuk, hogy az emberek információt keresve folyamodnak a közösségi médiához, mert a hagyományos (mainstream) médiát követni egyszerüen nem elég, különösen most, hogy a média és a tüntetők viszonya is feszültté vált. Sok tiltakozó nem ad interjút a hagyományos sajtó munkatársainak, sőt egyenesen ellenségesen viszonyulnak hozzájuk. A másik oldalról az »alternatív«, a »független«, vagy állampolgári média - használjuk bármely elnevezést - elkezdte betölteni ezt a megnyílt teret" (Medeiros, 2013).

Az új elektronikus médiumok segítségével az ember megszabadulhat bizonyos hatalmi berendezkedések ,felülről lefelé” irányuló politikájától, amelyben szigorúan szervezett politikai és/vagy gazdasági erők egyoldalúan gyakorolják a hatalmat. Mindezek folyományaként széles azon gondolkodók köre, akik az új médiumokat úgy üdvözölték, mint a politikai információk és eszmék erősen differenciált szolgáltatásának, minden hang elméletileg szinte korlátlan hozzáférésének, a vezetők és követőik közötti jóval több visszajelzésnek és egyeztetésnek az eszközeit, amelyek az érdekcsoport-alakítás és a véleményalkotás új fórumainak ígérkeznek (McQuail, 2003, 123. o.).

Anyilvánossággalés a civil társadalommal kapcsolatos elképzelések nyomán született az a gondolat, hogy az új médiumok nagyon is alkalmasak a privacy ${ }^{6}$ és az állami tevékenység tartománya közötti civil társadalmi tér betöltésére (McQuail, 2003, 123. o.).

Elmondható, hogy a digitális média valóban lehetőségeket biztosít a társadalmi kölcsönhatások új alakzataihoz, új módszereket kínál az idő és a tér korlátainak leküzdéséhez, és adott esetben azok befolyásolásához is. Ezért a közösségi médián keringő tartalmak bizonyos fokig hasonló funkciót tölthetnek be, mint a véleménynyilvánításnak a mitológiai, alakváltó Próteuszhoz hasonlóan a történelem során más-más formában felbukkanó felületei, a titkos pamfletektől, a falfirkákon át a szamizdat-kiadványokig (Iványi, 2014a).

Ám ez csupán az érem egyik oldala. Ha a közösségi média jelentőségét meg akarjuk érteni, meg kell vizsgálnunk azt is, hogy technológiai tulajdonságai miként kereszteznek más társadalmi tényezőket.

Az internetes és a hagyományos média (az újságok, a magazinok, a könyvek, a zene stb.) "offline" cenzúrája egyaránt felveti a megvalósíthatóság és a véleménynyilvánitás szabadságának kérdéseit. Különbség azonban, hogy az országhatárok áthatolhatóbbak a világhálón: egy cenzúrázó állam polgárai hozzáférhetnek ezekhez a tartalmakhoz olyan honlapo-

kon, amelyek szervere az országhatáron kivül található, igy a cenzoroknak azon kell munkálkodniuk, hogy annak ellenére is megakadályozzák a hozzáférést ezekhez a tartalmakhoz, hogy sem fizikálisan, sem jogilag nem férnek hozzá feltétlenül magukhoz az oldalakhoz.

Ami az internet cenzúráját magát illeti, ez a világhálón hozzáférhető tartalom ellenörzése és adott esetben elfojtása. Érdemes utalni arra, hogy mindez nem kizárólag a tekintélyelvü rendszerek sajátja, hiszen demokratikus kormányok, befolyásos gazdasági érdekcsoportok és magánszervezetek is élhetnek ilyen módszerekkel.

Amint a hagyományos cenzúra esetében, úgy az internetes tartalomkontroll esetében is, a módszerek, motívumok, a kiterjedés és a hatékonyság országonként nagy eltéréseket mutat. Politikailag nem korrekt, szerzői jogokat sértő, rágalmazó, felségsértő, hittérítő, 
zaklató, obszcén stb. tartalmak esetében is érvényt nyerhet a cenzúra. Amíg egyes országokban a korlátozással tulajdonképpen csak speciális esetekben találkozni (lásd lentebb), addig más országokban már az egyes hírforrásokhoz való hozzáférés is el van lehetetlenítve, csakúgy, mint az állampolgárok közötti véleménycsere (Dutton és mtsai, 2011).

Az internetes cenzúra motívumai négy nagyobb halmazba csoportosíthatók, tehát lehetnek (1) a politikával és a hatalommal; (2) a társadalmi normákkal és erkölccsel; (3) biztonsági megfontolásokkal és (4) a létező gazdasági érdekeltségekkel kapcsolatosak (Faris és Villeneuve, 2008).

Az internetes és a hagyományos média (az újságok, a magazinok, a könyvek, a zene stb.) „offline” cenzúrája egyaránt felveti a megvalósíthatóság és a véleménynyilvánítás szabadságának kérdéseit. Különbség azonban, hogy az országhatárok áthatolhatóbbak a világhálón: egy cenzúrázó állam polgárai hozzáférhetnek ezekhez a tartalmakhoz olyan honlapokon, amelyek szervere az országhatáron kívül található, így a cenzoroknak azon kell munkálkodniuk, hogy annak ellenére is megakadályozzák a hozzáférést ezekhez a tartalmakhoz, hogy sem fizikálisan, sem jogilag nem férnek hozzá feltétlenül magukhoz az oldalakhoz.

\section{A közösségi média és a véleménynyilvánítás szabadságának korlátai}

Az online cenzúra a maga drasztikusságában arra a kérdésre egy sajátos válasz, hogy milyen véleményt szabad nyilvánítani és milyet nem, illetve lefordítva az online közösségi hálózatok világának terminusaira: mi osztható meg és mi nem. Ám további kérdések is felmerülnek, elsődlegesen, hogy mi a teendő egy-egy vonatkozó esetben?

Cass Sunstein könyvében azt a kérdést feszegeti, hogy a véleménynyilvánítás szabadsága korlátozható-e bizonyos esetekben. Például amikor egy internetes oldal abortuszt végrehajtó orvosok neveit és elérhetőségeit osztja meg, mint a The Nuremberg Files, kifejezett utasításokkal arra nézve, hogy hol és hogyan lehet őket meggyilkolni. Vagy, hogy bombákat hogy lehet összeszerelni, hogyan lehet és hol érdemes felrobbantani öket, vagy, hogy terroristák hol hajtsanak végre támadásokat. Vajon felfogásunkban az árak versenytársak általi megszabásának és más versenyellenes gyakorlatoknak van-e helye a világhálón? A filmek, zenék, könyvek illetéktelen másolása és értékesítése tucatnyi vagy millónyi ember számára elnézhető-e? (Sunstein, 2009, 166. o.)

Azt, hogy az 1976 óta nemzetközi törvényi erővel rendelkező egyezmények milyen szemléletmódot tükröznek (PPJNE, EJEE), már az elöző fejezetben megvizsgáltuk. Kiterjedt számú jogi kihívás elé néznek azok a kísérletek, amelyek a Google-hez hasonló internetes szolgáltatókat és a webtárhelyeket felelőssé tennék törvénytelen, harmadik féltôl származó tartalom megosztásáért, illetve amelyek a közösségi hálózatok működ(tet) éséhez kapcsolódó adatvédelmi és internetes kalózkodást illető aggályokra irányulnak (McGoldrick, 2013). Tendenciózus növekedést mutat ugyanakkor a gyermek- és fogyasztóvédelmi megfontolásokból történő szabályozás-ellenőrzés.

Vajon mit tehet maga az online közösségi hálózat? Amennyiben valaki jelenti a szélsőséges, megosztó tartalmakat, a Facebook vagy a Twitter kész megvizsgálni és adott esetben eltávolítani is öket. A tartalmakat blokkolni nem egyszerü, különösen, ha ez egyértelmü iránymutatás nélkül történik, amint arra Laura Hudson egy más téma kapcsán, a nők elleni erőszak áldozatait ábrázoló fotókkal elnéző, azokat a jelentések ellenére sem törlő facebookos attitüd kapcsán rámutat. Maga a Facebook azt állítja, nagyon komolyan veszi a Jogok és Felelösségek Nyilatkozatát és nagyon gyorsan eltávolítja a jelentett, „házirendjüket” megsértő tartalmakat: 
„Általában a hangulatkeltő szándékból megosztott dolgok - még ha gusztustalanok és ízléstelenek is - nem sértik meg ezen irányvonalat. Ha azonban valódi fenyegetésről vagy gyülölködő kijelentésekről van szó, azokat eltávolítjuk. Arra biztatjuk az embereket, hogy az e célból az oldalon elhelyezett, feljelentő linkek segítségével tegyenek jelentést mindenről, amiről úgy érzik, hogy megsérti házirendünket."

Robert Beckhusen kedvező fejleménynek tartja, hogy a másik közösségi hálózatóriás, a Twitter a közelmúltban szintén például neonáci tartalmak elutasítása mellé állt, ám szerinte ez egy kimerítő küzdelem. Az amerikai oknyomozó újságíró két megoldást ajánl:

„Elöször azonosítani kell a leginkább vaskalapos felhasználókat, majd blokkolni őket, ami a többiek felszívódásához vezet. Egy másik megoldást jelenthet az, ha megakadályozzák a hozzáférést azokhoz a Youtube videókhoz, amelyek táplálják a Twitteres újramegosztásokat." (Iványi, 2014b)

Felmerülnek azonban további kérdések is: lehet-e attól még legitim egy véleménynyilvánítás az OKH-ok felületein, ha adott esetben sértő is (lásd: a véleménynyilvánítási szabadság és az emberi méltóság állandó tusája), ám ezek megválaszolása nemcsak túlmutat jelen írás keretein, de az eltéró jogrendek és legföképp az esetek végtelen száma miatt lehetetlen vállalkozás is és eleve legfeljebb csak tendenciák figyelhetők meg. Arról nem is beszélve, hogy a jog esetlegesen, a tények és az értékek folyamatosan változó, képlékeny állapota miatt tudatosan igyekszik szük és konkrét esetekre vonatkozó rendelkezéseket hozni, amelyek a jövőre nézve kevés útmutatást és kényszert határoznak meg.

Azzal a kérdéssel kapcsolatban ugyanakkor, hogy érheti-e jogállamban hátrány például a munkaadó részéről egy az online közösségi hálózatokon véleményt nyilvánító személyt és ilyenkor milyen elvek érvényesülhetnek az igazságszolgáltatási eljárás során, érdemes megvizsgálni a következő esettanulmányt, amelyet részletesen tárgyalunk.

A nemzetközi emberi jogok professzora a Nottinghami Egyetemen. Dominick McGoldrick (2013) bemutatja a Smith kontra Trafford Housing Travel ügyet, ami 2012. novemberben egy legfelsőbb bírósági ítéletben csúcsosodott ki, amely kidomborította az OKH-okon megjelenő tartalmakra vonatkozó döntések emberi jogi kiterjedését. Smith a Trafford Housing Trust munkatársa volt. Miután számítógépén elolvasta a BBC online kiadásán megjelenő cikkét, amelynek címe Zöldlámpát kap a meleg esküvői házasság, megosztotta azt Facebook-oldalán, hozzáfüzve annyit, hogy: „túl messzire ment egyenlöség”. Smith több mint kétszáz Facebook-baráttal rendelkezett, közülük a legtöbben keresztények, egy részük (45 fö) pedig munkatárs. Smith legtöbb bejegyzése a sportról, ételekről, motorbicikliről és autókról szólt. Facebook-profilja feltüntette munkaadóját és foglalkozását. Smith egyik kollégája, S kommentárt füzött mindehhez, érdeklödve, hogy ezek szerint a fejleménnyel nem ért-e egyet. Smith válasza így szólt: „Nem igazán. Nem értem, hogy olyan emberek, akik nem hívők és nem hisznek Krisztusban, miért akarnak templomban esküdni. A Biblia tisztán fogalmaz, amikor azt mondja, hogy a házasság férfi és nő közössége. Ha az állam lehetővé teszi a polgári esküvőt azonos nemüek számára, az az állam dolga; de az állam ne vesse ki szabályait a hit és lelkiismeret helyeire." Két hozzászólásáért Smith-t állásában felfüggesztették. A cég által indított fegyelmi eljárások úgy találták, hogy súlyos kötelezettségmulasztást követett el, amely miatt elbocsátást érdemel. Végül hűséges szolgálatának hosszú múltjára tekintettel nem vezetői munkakörbe helyezték, 40 százalékos bércsökkentéssel.

A meginduló igazságszolgáltatási eljárás során többek között felmerülö, főbb tisztázandó kérdések a következők voltak: A cég magatartási kódexe és esélyegyenlőségi irányvonala kiterjed-e Smith Facebook-fiókjára, illetve hogy Smith két hozzászólása ellentmondott-e az előbbiekben foglaltaknak, vagy szellemiségüknek? Ronthatták-e Smith bejegyzései a cég 
hírnevét, tekintve, hogy munkaadója és hivatása szerepel az adatlapján? A bíróság végül elutasította ezt az érvet és megállapította, hogy semmilyen formában és értelemben nem sérült a cég hírneve, minthogy senki sem értékelhette Smith magánvéleményét cége álláspontjának kifejeződéseként.

Felfoghatók voltak-e Smith bejegyzései vallási nézeteinek promóciójaként, és az ellentétes volt-e a magatartási kódex ügyfelekkel, nyilvánossággal és munkatársakkal való kapcsolatokra vonatkozó rendelkezéseivel? A bíróság ennek az érvelésnek sem adott helyet, minthogy a szóban forgó bejegyzések nem tekinthetők „promóciónak” és azok esetében nem állt fel munkahelyi vonatkozás sem, továbbá a munkatársak és a Facebook-barátok közötti átfedés ellenére sem voltak megállapíthatók „munkahelyi keretek”, hiszen Smith oldalát elsősorban magánjellegü dolgokra használta.

Smith bejegyzései vajon tükröztek-e méltóságot és tiszteletet a kollégái iránt, nem voltak-e azok ítélkező jellegüek, másoknak kényelmetlenséget, zavart, felháborodást okozók, sértve a cég magatartási kódexét és esélyegyenlőségi irányvonalát? A bírói álláspont nagy hangsúlyt fektetett a véleménynyilvánítás szabadságára: a politikai és vallási nézetek őszinte, ám törvényes kifejezése gyakran akarva-akaratlanul is okozhat bizonyos fokú felháborodást, sőt akár meg is sértheti az ellentétesen véleményen lévőket. Ez a véleménynyilvánítás ára. Smith-nek a homoszexuálisok templomi esküvőre vonatkozó hozzászólásainak tartalma, objektíve nézve, nem volt sem ítélkező, sem tiszteletlen, sem olyan, amely felháborodást, vagy sértést okozhat; egy széles körben osztott nézetet képviselt, amelynek gyakran adnak hangot például az audiovizuális médiumokban vagy a nyomtatott sajtóban. A bíróság szerint formailag pedig Smith nyelvezete mérsékelt volt, diplomatikusan és törvénytisztelően fogalmazott.

Végül a Legfelsőbb Bíróság olyan határozatot hozott, hogy a cégnek nem volt joga lefokoznia Smith-t utóbbi Facebook-bejegyzései miatt, illetve, hogy az állítólagos fegyelmi szankció útján kiszabott lefokozás szerződésszegésnek minősült. A cég azonnal elfogadta a bírósági döntést és teljes és őszinte bocsánatkéréssel élt.

A Smith-ügy kimondottan érdemes arra, hogy alaposan tanulmányozzuk, a maga elvi és ésszerü megközelítése miatt. A véleménynyilvánítás jelentőségének joggal kölcsönöz hangsúlyt, miközben mind a polgári jogi felelösségtudat, mind a munkaadók által kezdeményezett fegyelmi akciók száma növekszik. Arra is példa egyúttal, hogy abban az esetben, ha a magánszektor esetlegesen „öntörvényüen” értelmezi a közösségi média által megnyilvánuló véleménynyilvánítási szabadságot, az Államnak lehetősége van és felelös igazságot szolgáltatni.

McGoldrick (2013) a következő észrevételeket teszi mindezzel kapcsolatban: ,a munkaadóknak világos és hatékony vezérelvek lefektetésére van szükségük az OKH-ok használatára, ellenőrzésére és arra vonatkozólag, hogy ezek megsértése esetén mi történik. A szövegkörnyezet, a tartalom, a „hangszín”, a modor és a nyelvezet figyelembevétele elengedhetetlen és tárgyszerüen kell azokat értékelni. Közhelyes megállapítás, hogy a technológiai fejlődés mindig a törvények elött jár egy (?) lépéssel, éppen ezért az OKH-ok gyors fejlödése megköveteli, hogy világszerte találékony és körültekintő módon gondolják újra a jogi szabályozásokat.

Ennek alátámasztására a következő, részben egymással összefüggő hatásokat és tényezőket azonosíthatjuk. Jogi értelemben az OKH általi kommunikáció nem felel meg a barátokkal például egy kávézóban, bárban folytatott élő beszélgetéseknek. Verba volant, scripta manent: előbbinek írásos nyoma van, márpedig egy-egy megfogalmazás tartalma és formája más megítélés alá eshet a véleménynyilvánítás közege miatt.

A közönség is potenciálisan sokkal szélesebb, különös tekintettel a keresőprogramok képessége által lehetővé tett exponenciális és tartós nyilvánosságra, amelyben egy-egy bejegyzés részesül, és azokra az automatizált programokra, amelyek a nyilvánosan megosztott adatok gyüjtésére szakosodtak. 
A technológia megváltoztatta azokat a módokat, ahogy az egyének kommunikálnak és részt vesznek a közbeszédben. Az OKH-ok annak a modern megfelelöjét képviselhetik, ami korábban a magán-, a családi, a kisközösségi vagy belföldi szférák sajátja volt, amire a törvény inkább nem terjedt ki.

Lényegében a Facebook tömeges elterjedése megváltoztatja magát a privacy-t is, és következésképpen azt is, ahogy a felhasználók értelmezik és kezelik az ezzel kapcsolatos vonatkozásokat. Raynes-Goldie (2010) tanulmánya rámutat, hogy van, ami azt jelzi, hogy az OKH-felhasználók becsülik a privacy-t, de inkább társadalmi értelemben - információik mások általi fel- és kihasználását illetően -, mint intézményi értelemben, ezt érzékeltette a Smith-ügy is. Míg az emberek absztrakt értelemben foglalkoznak a 'privacy'-vel, a gyakorlatban már kevéssé teszik.

A Facebook-alapító Mark Zuckerberg szerint fel kell ismerni azt, hogy a privacy többé már nem egy társadalmi norma, hanem valami, ami az idők során (a közelmúltban) megváltozott (Johnson, 2010). Az OKH-színtéren nehéz különbséget tenni sértés és elfogadható (bár megdöbbentően kifejezett) megnyilvánulások között (McGoldrick, 2013).

Ezek már a szabályozás kérdései, amelyek óhatatlanul is újra felidézik a véleménynyilvánítás pozitív és negatív szabadságának polémiáját.

McGoldrick (2013) felismeri, hogy általában az OKH jogi szabályozása kihívást jelent, hiszen nem illik azokhoz a paradigmákhoz, amelyekre a véleménynyilvánítási szabadságra vonatkozó jogszabályok épülnek. „Elmosódik az egyéni és kiscsoportos kommunikáció, illetve a tömegkommunikáció között húzódó határvonal, ahogy az egyéni kommunikáció és a szervezetek, intézmények között futó mezsgye is." Konklúziója az, hogy talán nem hiteles és nem szerencsés az újságírás és a müsorszórás emberi jogok mentén a tömegkommunikáció intézményes szférájára irányultan bevezetett magas szabványait egyének vonatkozásában érvényesíteni. A jogszabálynak alkalmazkodnia kell, mind az anyagi jog, mind a jogorvoslat területein. ${ }^{7}$

Sunstein - akinek a véleménynyilvánítási szabadsággal kapcsolatos álláspontjáról már hazája jogalkalmazását illetően szóltunk - szerint fontos különbséget tenni a kimutathatóan káros és a viszonylag ártalmatlan beszéd (önkifejezés) között. Szerinte a hatalomnak az utóbbit nem szabad szabályoznia, sem a mindennapi valóságban, sem a világhálón. Szintén meg kell különböztetni azt a beszédet, amely a demokratikus (azaz a közérdek által meghatározott) önkormányzáshoz kapcsolódik és azt, amely nem.

Jelen írás semmiképpen nem kívánt abban az értelemben normatív lenni, hogy egyfajta váteszi szerepfelfogással felruházva, vagy szubjektivisztikusan irányokat jelöl ki a jogalkotás számára, és ez már csak egyéb fókuszpontjai miatt sem áll módjában.

Arra kívánta felhívni a figyelmet, hogy az online közösségi hálózatok megjelenése a közelmúltban új rétegekkel kezdte ellátni felfogásunkat a véleménynyilvánítási szabadságról, amelynek megítélése már eredendően is állandóan változott az idők folyamán, és amelynek értelmezését az eltérő történelmi fejlődésü országok különböző jogrendjének kulturális hagyományai, az emberi méltóság, a gyülöletbeszéd, vagy a nemzetbiztonság csak, hogy említsünk párat a teljesség igénye nélkül - szempontjai miatt eleve nem övezi konszenzus.

Az új technológiák kétségtelenül forradalmasították a kommunikációt és talán a nyilvánosság erőtanát is, ám tulajdonságaik tárgyszerü megítéléséhez nélkülözhetetlen látnunk, hogy azok miként kereszteznek más társadalmi tényezőket. Gondoljunk csak a feltételezésre Bahdzsattal kapcsolatban, aki ugyan feltehetőleg egy online közösségi hálózaton nagyobb biztonsággal mondhatta volna el véleményét a szegregált utazásról, ám bizonyos hatalmi válaszok, amelyeket a második fejezet érintett, tekintetében ez talán még sem garantált. Igaz ez a harmadik fejezetben részletezett Smith-ügyre is, ahol a privacy-fogalom módosulásainak ténye és ennek igazságszolgáltatási felismerése és törvényszéki implikációi elevenedtek meg. 
Ennek szellemében törekedett a tanulmány a negatív és pozitív szabadságok koncepcióinak bemutatására, továbbá arra, hogy utaljon az új helyzetet teremtő technológiához füződő viszonyaik tisztázásának relevanciájára.

\section{Irodalomjegyzék}

Achbar, M. és Wintonick, P. (1992): Manufacturing Consent: Noam Chomsky and the Media. 2014. 07. 29-i megtekintés, http://www.youtube.com/watch?v=RO51ahW9J1E

Angelusz Róbert (1996): Optikai csalódások. Pesti Szalon, Budapest.

Boller, Jr., P. F. és George, J. (1989): They never said it: A book of fake quotes, misquotes, and misleading attributions. Oxford University Press, New York.

Barton, H. A. (1986): Scandinavia in the revolutionary era - 1760-1805. University of Minnesota Press.

Castillo, A. (2010): Banned Books: Censorship in Eighteenth-Century England. Grin Verlag.

Charlesworth, M. P. (1943): Freedom of Speech in Republican Rome. The Classical Review (The Classical Association), 57. 1. sz. 49. DOI: 10.1017/ s0009840x00311283

De Sola Pool, I. (1983): Technologies of freedom. Harvard University Press.

Dutton, W. H., Dopatka, A., Law, G. és Nash, V. (2011): Freedom of connection, freedom of expression: the changing legal and regulatory ecology shaping the Internet. Division for Freedom of Expression, Democracy and Peace, United Nations Educational, Scientific and Cultural Organization (UNESCO), Paris

Dworkin, R. (2009): Foreword. In: Hare, I. és Weinstein, J. (2009): Extreme speech and Democracy. Oxford University Press. DOI: 10.1093/acprof:oso/9780199548781.001.0001

Faris, R. és Villeneuve, N. (2008): Measuring global filtering. In: Deibert, R., Palfrey, J., Rohozinski, R. és Zittrain, J. (szerk.): Access Denied: The Practice and Policy of Global Internet Filtering. MIT Press, Cambridge. 2014. július 28-i megtekintés, https://opennet. net/sites/opennet.net/files/Deibert 02_Ch01_005-028. pdf

Gálik Mihály és Polyák Gábor (2005): Médiaszabályozás. Libri, Budapest.

Ghoneim, V. (2013): Forradalom 2.0. Gabo, Budapest.

Habermas, J. (2005): A posztnemzeti állapot. Politikai esszék. L'Harmattan, Budapest.

Heyman, S. (2009): Free speech \& Human dignity. Yale University Press, New Haven - London.

Iványi Márton (2014a): Közösségi média: a nyilvánosság elektronikus agorája vagy posztmodern panoptikum? Hatalmi válaszok a közösségi média kihívásaira. Médiakutató, 2. sz. 2014. 07. 29-i megtekintés, http:// www.mediakutato.hu/cikk/2014_02_nyar/10_kozossegi_media_hatalom.pdf

Iványi Márton (2014b): Széttöredezett nyilvánosság? Az online közösségi hálózatok és a radikalizmus. Jel-Kép, 1. sz. 2014. 07. 29-i megtekintés, http://communicatio.hu/jelkep/2014/1/ivanyi marton.htm

James, S. és Cohen, L. (2012): Tightening the Net: Defamation Reform. Latham \& Watkins. In Practice Newsletter.

Johnson, B. (2010): Privacy no longer a social norm, says Facebook founder. The Guardian. 2014. 07. 24-i megtekintés, http://www.theguardian.com/techno$\operatorname{logy} / 2010 /$ jan/11/facebook-privacy

Kiss, J. (2014): Facebook's 10th birthday: from college dorm to 1.23 billion users. The Guardian. 2014. 07. 22-i megtekintés, http://www.theguardian.com/technology/2014/feb/04/facebook-10-years-mark-zuckerberg

Koltay András (2012): A sajtószabadság fogalma. 2014. 07. 22-i megtekintés, http://mediatorveny.hu/ dokumentum/143/Koltay_A_A_sajtoszabadsag.pdf

Koltay András (2013): A gyülöletbeszéd korlátozása Magyarországon. Alkotmányos és jogalkalmazói megközelitések, európai kitekintéssel. Complex, Budapest.

Kommunikációtudományi Nyitott Enciklopédia, Véleménynyilvánitás címszó. (é. n.) 2014. 07. 29-i megtekintés, http://ktnye.communicatio.hu/index.php?title $=\mathrm{V} \% \mathrm{C} 3 \% \mathrm{~A} 91 \mathrm{em} \% \mathrm{C} 3 \% \mathrm{~A} 9$ nynyilv $\% \mathrm{C} 3 \% \mathrm{~A} 1 \mathrm{n} \% \mathrm{C} 3-$ $\% \mathrm{ADt} \% \mathrm{C} 3 \% \mathrm{~A} 1 \mathrm{~s}$

Moslih, H. (2014): Is the concept of human rights non-ideological? Al Jazeera Online. 2014. október 6-i megtekintés, http://www.aljazeera.com/indepth/opinion $/ 2014 / 08 /$ concept-human-rights-non-ideolog-20148139355416640.html

Muḥsin aš-Šayh Āl Hassān (2013): Hurrīyya ar-Ra’y wa't-ta 'bīr fì'l-Islām. Al Sharq. 2014. 07. 22-i megtekintés, http://www.alsharq.net.sa/lite-post?id=824559

Israel, J. (2002): Radical Enlightenment. Oxford University Press. DOI: 10.1093/acprof:oso/9780198206088.001.0001

La Rue (2011): Report of the Human Rights Council's Special Rapporteur on the promotion and protection of the right to freedom of opinion and expression, A/ HRC/17/27, 16 May 2011, at para 2.

MacQueen, H. L., Waelde, Ch. és Laurie, G. T. (2007): Contemporary intellectual property: law and policy. Oxford University Press.

McGoldrick, D. (2013): The limits of the freedom of expression on Facebook and social networking sites: a 
UK perspective. Human Rights Law Review, 13. 1. sz. 125-151.

McQuail, D. (2003): A tömegkommunikáció elmélete. Osiris, Budapest.

Medeiros, D. (2013): 'Mainstream Media Isn't Enough': The Rise of Brazilian Media Collective Nigeria. English Global Voices. 2014. 07. 24-i megtekintés, http://globalvoicesonline.org/2013/10/01/mainstream-media-isnt-enough-the-rise-of-brazilian-media-collective-nigeria/

Pais István (2005): A filozófia története. Szerzői kiadás.

Raaflaub, K., Ober, J. és Wallace, R. (2007): Origins of democracy in ancient Greece. University of California Press. DOI: $10.1525 / \mathrm{cal}$ ifornia/9780520245624.001.0001

Raynes-Goldie (2010): Aliases, Creeping and Wall Cleaning: Understanding Privacy in the Age of Facebook. First Monday. 2014. 07. 29-i megtekintés, http:// www.uic.edu/htbin/cgiwrap/bin/ojs/index.php/fm/ article/view/2775/2432 DOI: $10.5210 /$ fm.v15i1.2775
Sanders, K. (2003): Ethics \& journalism. Sage. DOI: $10.4135 / 9781446220467$

Szabó Máté Dániel (2005): Kísérlet a privacy fogalmának meghatározására a magyar jogrendszer fogalmaival. Információs Társadalom. 2014. 07. 29-i megtekintés, http://www.infonia.hu/digitalis folyoirat/2005_2/2005_2_szabo_mate_daniel.pdf

Székely László (2013): Előszó a gyülöletbeszéd korlátozásához Magyarországon. Complex, Budapest.

Tamer, Z. (2008): Breaking knees. Modern Arabic Short Stories from Syria. Garnet Publishing Limited, Reading.

Vajic és Voyatis (2012): The Internet and Freedom of Expression: A „Brave New World” and the ECtHR's Evolving Case Law. In: Casadevall és mtsai (szerk.): Freedom of Expression. Wolf, Oisterwijk.

Warburton, N. (2009): Free speech: A very short introduction. Oxford University Press. DOI: 10.1093/actrade/9780199232352.001.0001

\section{Jegyzetek}

${ }^{1}$ Ezzel a meghatározással konform az Alkotmánybíróság 36/1994. (VI. 24.) határozata is, mely azt rögzíti, hogy az Alkotmány nem tesz kifejezett különbséget a véleménynyilvánítás szabadságának tárgyalásakor a tényközlés és az értékítélet között, azaz mindkettőt véleménynyilvánításnak tekinthetjük.

${ }^{2}$ Hagyományos cenzúra valamely formában ,az emberi közösségek alá- és fölérendeltségi viszonyainak, az információk extraszomatikus tárolásának, és különösen a tömeges információáramlási formáknak a megjelenése óta" létezik (Iványi, 2014a).

${ }^{3}$ A muszlim perspektíva már csak azért is releváns, mert időről időre felmerül egyik oldalon a véleménynyilvánítás szabadságának, a másik oldalon az emberi méltóság és vallási érzékenység értékeinek ütközése olyan esetekben, amikor különféle karikatúrák sértik a muszlimok vallási meggyőződését.

${ }^{4}$ Sunstein $(2009,178-179$. o.) szerint ,aa véleménynyilvánítás szabadság demokratikus koncepciójában semmi újdonság vagy tekintélyromboló nincs. Éppen ellenkezőleg, Amerikában ez a koncepció áll a szólásszabadság eredeti értelmezésének középpontjában”. Ennek alátámasztására feleleveníti, hogy James Madison az idegenekről és lázadásokról szóló törvényt (Alien and Sedition Acts) éppen azért támadta, mert ,az ellen a jog ellen irányul, hogy az emberek szabadon vizsgálhassák a közszereplőket és az állami intézkedéseket, és hogy szabadon kommunikálhassanak minderröl, amelyet mindig is joggal tartottunk minden más jog egyetlen hatékony oltalmazójának."

${ }^{5}$ Tegyük hozzá azonban, hogy néhány országban a helyi hálózatok továbbra is meghatározóak, például az orosz VKontakte több mint százmillió taggal büszkélkedhet - ami lényegesen felülmúlja a Facebookon regisztrált orosz felhasználók számát -, a kínai RenRen alkalmazásait igénybe vevők pedig több mint harminc millióan vannak (McGoldrick, 2013).

${ }^{6}$ A magyar nyelvben nincs megfelelő szavunk, amely visszaadhatná az angol 'privacy' szó lényegét, amely a magyar magánélet szónál lényegesen tágabb értelmü. Gondolatmenetünk szempontjából a 'privacy' az a privát szféra amelyben az ember önmaga lehet és önmaga maradhat, az az a rólunk szóló tudás feletti ellenőrzés gyakorlásának lehetősége" (Szabó, 2005). A szövegben éppen ezért maradunk az angol privacy használatánál, amelyet mégis talán úgy adhatnánk vissza, mint egyének, egyének csoportjai és intézmények az iránti igénye, hogy meghatározhassak, a rájuk vonatkozó információk mikor, hogyan és milyen mértékben juthatnak mások tudomására.

${ }^{7}$ A korszerü jogi szabályozásra példa a 2012-es rágalmazás-ellenes törvény Nagy-Britanniában, amely a felhasználók által előállított tartalmaknak otthont adó honlapok üzemeltetöinek védelméről rendelkezik, feltéve, ha lehetővé teszik, hogy a panaszos a vitás kérdéseket közvetlenül a tartalom közzétevőjével rendezze (James és Cohen, 2012, 2-5. o.). Egy további lehetőség, amely lehetővé tudná tenni a bírságok kiszabásának és kártérítési kötelezettségek megállapításának az elkerülését, ha a törvényszék utasíthatná magát a törvénybe ütközö üzenetet közzétevő OKH-ot a tartalom eltávolít(tat)ására és akár a megfelelő bocsánatkérés, magyarázat, helyreigazítás stb. mellékelésére is, ahogy ezt a tömegmédia teszi. 